\title{
Influence of Organizational Justice on Employee Engagement in Tertiary Institutions in Edo State, Nigeria
}

\author{
John Omogeafe Ohiorenoya, (PhD, MBA, B.Sc) \\ Benson Idahosa University, Nigeria \\ Evans Osaruwmen Eguavoen, (M.Sc, B.Sc) \\ Church of God Mission, Nigeria
}

Doi:10.19044/esj.2019.v15n28p56 URL:http://dx.doi.org/10.19044/esj.2019.v15n28p56

\begin{abstract}
This study empirically investigated the influence of organisational justice on employee engagement in the tertiary institutions in Edo State. Its specific objectives were to examine the influence of distributional, procedural and interactional justice on employee engagement in the tertiary institutions in Edo State. In achieving these objectives, the study adopted the cross sectional survey research design. It specifically made use of data collected from four hundred and one (401) staff of the tertiary institutions in Edo State. Data collected were analysed with descriptive and Ordinary Least Square regression. The study revealed that organisational justice has significant influence on employee engagement in the tertiary institutions in Edo State. It also revealed that each of the dimensions of organisational justice: distributional, procedural and interactional positively and significantly influenced employee engagement in the the tertiary institutions in Edo State. From these findings, the study recommended that managements of the tertiary institutions in Edo State should increase their efforts in rewarding employees according to their workload, work completed, work contributed, relevant skills and educations acquired; increase effort in promoting those policies or procedures where employees can be promoted on time and as when due; provide employees with accurate, timely and adequate information to perform job and ensure all employees are treated with politeness, dignity, kindness, consideration and supported equally.
\end{abstract}

Keywords: Organisational justice, Employee engagement, Tertiary institutions 


\section{Introduction}

Employee engagement is the pivotal human resource strategy for an organisation to gain competitive advantage and cope in the face of complexity and dynamics of business environment (Albrecht, Bakker \& Saks, 2015). This belief stems from Shantz, Alfes Truss and Soane (2013) study that empirically linked employees' engagement to financial and non-financial performance. Saks (2006) reveals that engaged employees are not only more dedicated and loyal to the organization but also are more emotionally committed to the organization, experience heightened performance, reduced absenteeism, and a lessened likelihood of quitting their job.

Employees' engagement is a positive, fulfilling, work-related state of mind that is characterized by vigour, dedication, and absorption (Schaufeli, Salanova, Gonzalez-Roma, \& Bakker, 2002). Employee engagement increases when employees believes that organization values their contributions and cares about their well-being. This belief is directly influenced by perceived justice in reward systems such as promotion, wage and fringe benefits and job conditions (job security, training, autonomy and working hours, work allocations and provision of feedback) Eder and Eisenberger (2015).

Organizational Justice is individual's perceptions of fair treatment received in an organization. It is usually evaluated by comparing the reward employees receive from the job (salary levels, salary increases and recognition) to the effort, experience and education and competence put fairness in an organization when their efforts are equitably rewarded. They also perceive fairness when there is respect to procedures, policies.

Employees feel obligated to engage themselves in role and extra role performance when they perceive justice in an organization (Eder \& Eisenberger, 2015). However, most organizations in Nigeria do not promote fairness in dealing with employees even when they are the most critical resource in the organization whose actions and inactions determine the success of the organization (Oge, Ifeanyi \& Charles-Gozie, 2015). According to Oge et al (2015) injustice in Nigeria workplace has been increasing at an alarming rate. It is reflected in reward distribution, interpersonal treatment and even in the policies and procedure developed by some organizations. In most cases these policies and procedures are unclear, or immeasurable to those who design them. The unfair and deplorable working conditions employees experience result in tardiness, strikes, workplace assault, extensive absenteeism, sabotage(Efanga \& Akpan, 2015). These have also negatively affected psyche and morale of most Nigerian employees; making them unable to deliver on their job description (Igbinomwanhia \& Akinmayowa, 2013). Perceived injustice occasioned by unresponsiveness to workers plight, wage increment and better-working conditions, regular promotion and employers' 
unwillingness to fulfil contractual obligation with employees have made most Nigerian workers unenthusiastic in performing their duties (Amazue, Nwatu, Ome, \& Uzuegbu, 2016). This has created the impression that Nigerian employees are not engaged when in actual fact it is the perceived unfairness in workplace that make workers dissatisfied and thus lack of lack of work engagement (Karatepe, 2011).

While perceived justice in Nigeria workplace and its impact on employee's engagement earnestly call for research interests, most studies mainly focused on the relationship between perceived justice psychological wellbeing (Ajala \& Bolarinwa, 2015), satisfaction of individual employee (Okocha \& Anyanwu, 2016), organisational citizenship behaviours (Monanu, Okoli ,Ezeliora Okeke, 2016; Igbinomwanhia \& Akinmayowa, 2013; Efanga \& Akpan, 2015; Ucho \& Atime, 2013), employees commitment (Akanbi, Ofoegbu, \& Onyem 2013), work alienations (Amazue, Nwatu, Ome, \& Uzuegbu, 2016), and employee performance (Efanga, Aniedi \& Gomiluk, 2016). Though Karatepe (2011) appears to be the only study that attempted to link perceived organization justice on employees' engagement in Nigeria, the study however focused only on the link between procedural justice and employee's engagement and neglected the influence of distributive, interactional justice. It is against this backdrop that this study attempts to ascertain the influence of procedural, distributive, interactional justices on employees' engagement in tertiary institutions in Nigeria.

The objective of this paper, therefore, is to examine the relationship between organizational justice and employees' engagement in the tertiary institutions in Nigeria with focus on procedural, distributive, interactional justice.

\section{Research Hypotheses}

The following hypotheses were tested

a. Ho: There is no significant relationship between perceived distributive justice and employees' engagement in the tertiary institutions in Nigeria

b. Ho: There is no significant relationship between perceived procedural justice and employees' engagement in the tertiary institutions in Nigeria

c. $\mathbf{H}_{0}$ : There is no significant relationship between perceived interactional justice and employees' engagement in the tertiary institutions in Nigeria

\section{Employee Engagement}

Employee engagement has been seen variously as cognitive, emotional and physical commitment (Kahn, 1990), behavioural commitment (May, 
Gilson, \& Harter, 2004) and intellectual commitment (Shaw, 2005) to work roles.

While the definitions given above have provided insight into the concept of employees' engagement, nevertheless, the most widely cited conceptualization of employees' engagement was put forward by Schaufeli, Salanova, González-Romá \& Bakker (2002: 3) who defined engagement as "a positive, fulfilling, work-related state of mind that is characterized by vigour, dedication and absorption". According to Shaufeli et al. (2002) vigour involves energy, persistence, and resilience while working; dedication is a strong level of involvement in one's work, along with feeling of significance, enthusiasm, inspiration, pride, and challenge; absorption involves how concentrated and engrossed an employee is in their work, feeling as though time is passing quickly and they have difficulty detaching themselves from their work.

In supporting this view, indicate that engaged employees feel a high level of contentment while performing work, experience less burnout and are often fully immersed in their work (Baker \& Demerouti, 2014). Employees who are engaged in work role experience a positive fulfilling work-related state of mind such as happiness, joy, enthusiasm, energy during role performance and strong emotional attachment and identification with their work (Schaufeli, 2013). They are characterized by energy, involvement, and efficacy instead of burnout, exhaustion, cynicism and ineffectiveness (Saks, 2006) attention and absorption (Rothbard, 2001).

Flowing from the above, the definition of the concept of employees engagement is related to several other organizational constructs including employees commitment (emotional identification/attachment to an organization), job involvement (emotional identification to job activities), and satisfaction (pleasurable feeling or enthusiastic about the job).

This paper sees employee engagement as passion and commitment, the readiness to invest oneself and increase one's discretionary effort to support the employer's success, which is beyond simple satisfaction with the employment agreement and basic devotion to the employer (Macey \& Schnieder, 2008).

\section{Organizational Justice}

Organizational justice is a personal evaluation of the ethical and moral standing of managerial conduct (Cropanzano, Bowen, \& Gilliland, 2007). It is an individual's perceptions of fairness of various human resources practices (pay, reward or promotion opportunities, and interpersonal interaction of the organization (Greenberg, 1996). It is the extent to which employees are treated in just manner through appraisal of organizations' policies and 
procedures; interpersonal communications, and monetary and non-benefits derived from the organization (Nabatchi, Bingham, \& Good, 2007).

Greenberg and Baron (2009) also opined that organizational justice is the perception of fairness in workplace or organization, which is usually evaluated by comparing the reward employees receive (get) from the job (salary levels, salary increases, and recognition) to the effort, experience and education and competence put into the job. According to Greenberg and Colquitt (2015) employees perceived fairness in an organization not only when their effort are equitably rewarded in an organization but also with respect to the procedures, policies, and different interpersonal treatment they are subjected to in different circumstances in the organization. In this light, Greenberg (2005) draws from psychological contract and social exchange theories to categorized organizational justice into three distinctive dimensions namely distributive justice (referring to the fairness in outcomes (rewards) received for engaging in certain behaviour or effort), procedural justice (referring to fairness in the formal process by which rewards (outcomes) provided to employees, how works are allocated and performance evaluated are determined), and interactional justice (referring to fairness in interpersonal treatment including the dignity and respect that one receives in the process of evaluating their performance, distributing resources and rewards, allocating works, provision information and social supports).

Historically, organizational justice is rooted in equity theory developed by Adam (1965), which states that judgments of equity and inequity are derived from comparisons between one's self and others based on inputs (effort) and outcomes (pay and recognition individual get out of an exchange relationship). Accordingly, when the input-outcome ratio, compared to the ratio of the comparison other is unequal, the individual is motivated to restore equity by reducing inputs, or changing outcomes, or getting the referent others to change inputs or outcome, or quitting the job for a more equitable one. Inequitable comparisons result in a state of dissonance or tension that motivates the person to engage in behaviour designed to relieve tension. The theory of equity which has consistently been used to explain justice in an organization specifically suggests that employees who perceive inequity (undergo cognitive conflict when things go in contrast to their prospect) in work situations will make a change in the inputs by decreeing their effort. It indicated that because an individual is often very sensitive to the ways they are been treated, promoting fairness or justice in social settings including organization is a key factor to most to keep a satisfied, committed and loyal employee in the organization. However, fairness in most organizations in Nigeria is far from reality as Monanu, Okoli, \& Adibe (2015) indicated that most organization does not promote fairness in dealing with employee even when employees are a most critical resource in an organization whose actions 
and inactions determine the success of an organization. Moreover, Nwinyokpugi (2014) observed that Nigerian workplace has witnessed cumulative incidences of gross laxity and unattached commitment to work due to the practices of fair and unjust rewards. Perceived injustice has also raised a number of concerns including dissatisfaction with the job, psychological alienation (powerlessness and meaninglessness) that employees feel at work, and cognitively separation of an employee from work, which manifests itself in the form of decreased job involvement and poor psychological identification (Amazue, Nwatu, Ome \& Uzuegbu, 2016).

Organisational justice has historically been evaluated through three main proposed components of distributive, procedural, interaction justices (Cropanzano, Bowen \& Gilliland, 2007; Colquitt, 2001). This study draws on extant studies to provide understanding of distributive, procedural, and interactional justices.

Distributive justice, as defined by Greenberg (2005) is an individual's judgment or perceived fairness of resource allocation based on the produced outcomes of the individual compared to the expected inputs. It is the fairness associated with decision outcomes and distribution of resources (Igbinomwanhia \& Akinmayowa, 2014). The outcomes or resources distributed may be tangible (e.g., pay) or intangible (e.g., praise) (Cassar \& Buttigieg, 2015). Distributive justice therefore, is perceived fairness in the pay and fringe benefits received by employees when compared to needs, job demand, individual skill level, education and industry salary scale (Cropanzano, Bowen \& Gilliland, 2007). Distributive justice is employee judgment and perception that the pay and other financial rewards they get from the job is fair and commensurate with their job demand, skill level, education attainment and industry pay standard or industry salary scale) (Nabatchi, Bingham, \& Good, 2007). It is concerned with whether benefits received by employees are distributed fairly or not (Folger and Cropanzano, 1998). It focuses on people's belief, that they have received fair amounts of valued work-related outcomes (e.g. pay, etc). It is employees' perceptions of fairness of organizational outcomes or outcome distributions (wage, reward, promotion, etc.).

Distributive justice thus gives an idea about whether the individual's acquisitions (tasks, goods, wages, promotions, opportunities, rewards and punishment) are fair, appropriate and ethical. Individuals may perceive their outcomes (income, premium, promotion, social rights, etc.) as fair or unfair by comparing their outcomes (rewards) with those of others. They believe that the outcomes received are appropriate when they are based on equity (rewarding employees based on their contributions), equality (providing each employee roughly the same compensation) and needs (providing a benefit based on one's personal requirements). The theory of equity according to 
Bahrami, Montazeralfaraj, Gazar, and Tafti (2014) posits that individuals are satisfied when outcomes (benefits) are distributed on the basis of skills and efforts (contributions) and when the ratio of employees input to output equals the ratios of inputs to outcomes.

The equity theory suggests that individuals who perceive their ratio of inputs to be lower than the output received will not only be satisfied but feel obligated to put more effort in their work and actively participate in job activities. Supporting this, several contemporary studies have also concurred that employees are satisfied when the ratio of their job demand (work load, time pressure and long working hours) is equal to pay and fringes benefits received, and if not equal such individual employees may engage in equity restoration by putting less effort in their work (Omoruyi, Chipunza \& Samuel, 2011; Bahrami, Montazeralfaraj, Gazar, \& Tafti (2014). Employees who perceive their ratios of inputs to be higher than the outputs received may feel angry and engage in equity restoration, which can be done by decreasing the effort put into the job, alienating from job, engaging in tardiness, gratification (bribery), embezzlement and inflation of contracts and other illegitimate behaviours (Balogun, Ojedokun \& Owoade, 2016). Individual, who perceives organizational inequity, achieve or restore equity by increasing their effort if their input is less than output (e.g overpaid) or reduce effort if their effort if their input is greater than output ( e,g underpaid) (Uzondu, Adibe, Aloh \& Okafor, 2014).

Procedural justice is an individual's perception of fairness of organisational policies and procedures, process, methods, and mechanisms used in evaluating their work performance (Moorman, 1991; Dabbagh, Esfahani, \& Shahin, 2012 and Akanbi \& Ofoegbu, 2013).

In this regards, procedural justice refers to the fairness of means or process by which outcomes are allocated but not specifically to the fairness of outcomes themselves. Procedural justice is usually appraised on the basis of whether organisations equally apply rules and regulation to every member of the organisation, avoid bias in the decision-making process, ethical in correcting mistakes, adequately notify employees before decisions that affect them are implemented and providing equal opportunity for every member of the organization to be heard, appeal, receive accurate information and make input in the decision process (Cremer, 2005)

Studies have also demonstrated that when the structure, procedures or system of allocating resources is perceived as fair, the outcome received or distributed is likely to be perceived as fair (Karatepe, 2013; He Zhu \& Zheng, 2016).

Interactional justice is the social aspect of procedural and distributive justices (Greenberg \& Colquitt, 2015). It has been conceptualized as the quality of the interpersonal treatment received by an individual, both before 
and after decisions are made, enacted or implemented in the workplace (Greenberg, 2005). It is the degree to which supervisor(s) is fair when treating and rewarding subordinates (Moorman, Niehoff, \& Organ, 1993) and employees are treated with dignity and respects by supervisors (Colquitt, 2001). Interactional justice therefore exists when decision makers treat people with respect and sensitivity and explain the rationale for decisions thoroughly.

Employees perceive justice in interactional aspect of the job when they believe that supervisors provide them quality support, reward increased efforts and provide them with fair information concerning how outcomes are determined (Efanga, Aniedi \& Gomiluk 2015). Interactional justice, is the social aspect of a job which is divided into interpersonal justice and informational justice (Walumbwa, Cropanzano, \& Hartnell, 2009). The informational justice relates to the adequacy of the explanations about the policies and procedures given to employees in terms of their timeliness, specificity, and truthfulness, while interpersonal justice relate to perceived fairness that their supervisors care about their well-being and treat them with respect, dignity while evacuating their job performance (Ledimo \& Hlongwane, 2017).

Bies and Moag (1986) identify some key aspects of both interpersonal and information justices which can enhance people's perceptions of fair treatments. They are truthfulness (information given must be realistic and accurate, presented in an open and forthright manner), respect (employees treated with dignity), propriety (statements and questions should never be improper or involve prejudicial elements such as racism or sexism) and justification (when a perceived injustice has occurred, giving explanation or apology can reduce or eliminate the sense of anger generated).

This paper looks at interactional justice as the quality of interpersonal processes and treatment of individuals as well as the extent to which the reasons behind the outcome are explained. Interactional justice increases when managers provide honest information (not withhold information sharing) and willing to clarify the procedures used in determining and distributing outcomes (Colquitt \& Rodell, 2011). Employees perceived justice in interaction when information about decision process and outcomes is carefully designed and delivered purposefully (Baharifar, Javaheri \& Kamel, 2012).

The theoretical basis of this paper stems from the propositions of equity theory by Adams (1965), which hinges on the assumption that employees assess or evaluate the ratio of the effort invested into a job and output received from the job, and then compare the ratio with the input to output ratio of a referent. The theory believes that when the ratios differ, inequity is experienced, which in turn causes a conflict situation that elicits stress, low commitment, engagement and other work outcomes. Perceived equity exist when employees believe the outcome is equal or greater than what 
they deserve to get from their job given the inputs (Bing, Davison, Garner, Ammeter \& Novicevic, 2009).

Extending this theory, several studies have come to common consensus that employees evaluate fairness in the workplace in terms of procedural, distributive, and interactional encounter in the organization (Colquitt, 2005; Nabatchi, Bingham, \& Good, 2007; Greenberg \& Baron, 2009).

The proposed assumption by the theory that employees who perceive equity will increase effort and those who perceive inequity will decrease effort has also been supported by many empirical studies as they revealed that perceived justice increase employees satisfaction and wellbeing (Cassar \& Buttigieg, 2015), stimulate greater commitment (Ajala, 2015), lower sabotage (Ceylan \& Sulu, 2011), reduce stress and turnover intention (Greenberg, 2004), improve citizenship behaviour (Colquitt, 2001; Igbinomwanhia \& Akinmayowa, 2014), enhance trust and job performance (Ambrose, Seabright, \& Schminke, 2002), reduce work alienation (Amazue, Nwatu, Ome \& Uzuegbu, 2016) and induce employees engagement (Gupta \& Kumar (2012).

\section{Methodology}

The population of the study comprised of all employees of approved universities in Edo State, Nigeria that have gone through NUC accreditation process. The universities include University of Benin, Ambrose Alli University, Benson Idahosa University and Igbinedion University, University of Iyamho, Wellspring University and Tayo Akpata university of Education. University of Benin, Ambrose Alli University, Benson Idahosa University and Igbinedion University were chosen based on ownership (Federal, State, and Private Universities) and year of establishment.

The population of these four universities and their year of establishment are shown in Table 1 below.

\begin{tabular}{|lcc|}
\hline \multicolumn{3}{|c|}{ Table 1. } \\
The Population and sample size of Staff in Each of the Selected Nigerian Universities \\
\hline Universities & No of Staff & Sample Size \\
\hline University of Benin, Benin City & 5,890 & 235 \\
\hline Ambrose Alli University, Ekpoma & 2,548 & 101 \\
\hline Igbinedion University, Okada & 686 & 28 \\
\hline Benson Idahosa University, Benin City & 495 & 20 \\
\hline Total & 9,619 & 384 \\
\hline Population is as of 2017 & & \\
\hline
\end{tabular}

\section{Source: Fieldwork (2017)}

Sample size of three hundred and eighty four (384) staff of the universities was determined using Yamane (1967)'s formula as in Ohiorenoya 
(2013). The sample size was distributed to the four universities based on the proportion of the staff strength of each of the universities.

The questionnaire was administered using multi stage and stratified sampling techniques. The study divides each of the institutions into academic arm and non-academic arm. The academic arm of the universities consisted of faculty of Arts, education, science, social science, management, engineering, pharmacy, dentistry, school of medicine and the library and the non-academic arm consisted of the Vice- chancellor's office, the registry and the bursary and works department of the universities although these vary in nomenclature from university to university. The non-academic arm of each university was stratified into top management, middle management, supervisory management, technical and support staff in order to ensure that respondents cut across the different strata of the organization. The academic arm was stratified into professors, senior lecturers, lecturers and the administrative support staff (Ohiorenoya, 2014).

The research instrument was the questionnaire which was administered to all respondents. The questionnaire has two major sections. The first consists of the respondents' demographic characteristics while the second section is to gather the focal data on the opinions and views that lie at the core of the study. A Likert-type five-point scales ranging from 1 = strongly disagree, $2=$ disagree, $3=$ neutral, $4=$ agree and $5=$ strongly agree (with provision for reverse scoring) will be used to measure the perceptions of the respondents regarding employee engagement in organisations and the dimension of organisational justice.

The validity of questionnaire content was verified by the expert opinions of four seasoned HR practitioners to ascertain if the questionnaire items actually measured what they ought to measure. In terms of reliability thirty copies of the questionnaire were administered to different cadres in the four universities in Benin City. The data generated were analysed and used in assessing the reliability of the research instruments. Cronbach's alpha was used to test and detect the reliability of the instrument by calculating the internal consistency of each scale.

Table 3.4 shows the reliability of the questionnaires. The reliability of the items is discussed below.

Table 4: Reliability Test

\begin{tabular}{|r|l|c|c|}
\hline \multicolumn{1}{|l|}{ S/N } & Questionnaire Items & Cronbach's Alpha Value & Number of items \\
\hline 1. & Employee engagement & 0.896 & 17 \\
\hline 2. & Distributive Justice & 0.852 & 6 \\
\hline 3. & Procedural justice & 0.811 & 6 \\
\hline 4. & Interactional justice & 0.901 & 12 \\
\hline
\end{tabular}

Source: SPSS OUTPUT, 2017. 
The value of Cronbach's coefficient alpha of the employee engagement and dimensions of organisational justice ranging from low 0.811 to a high 0.901 are within the acceptable values of alpha, ranging from 0.70 to 0.95 , the criterion suggested by Nunnally (1978) and are therefore considered good indicators of the reliability of the instrument.

Six hundred (600) copies of questionnaire were administered with the aid of research assistants. Of the six hundred questionnaire administered, four hundred and one (401) of them were found usable. Specifically, we successfully surveyed 235 staff in University of Benin, Benin City, 101 staff in Ambrose Alli University, Ekpoma, 30 staff in Igbinedion University, Okada, and 35 staff in Benson Idahosa University, Benin, Benin City.

The data collected from the respondents were analysed using correlation and regression analysis. SPSS 16.0 was the statistical package used in the analysis.

Bivariate Pearson correlation coefficients were conducted on the data for all the variables in the study.

Table 5 shows the Pearson correlation coefficients among research variables.

Bryman and Cramer (1997) posit that the Pearson's correlation coefficient (r) should not exceed 0.80; otherwise the independent variables that show a relationship in excess of .80 may be suspected of having multicollinearity. However, we observed from table 5 that none of the correlation coefficients is up to .80 , thus ruling out any form of multi-collinearity in the model

Table 5: Pearson correlation coefficients among research variables

\begin{tabular}{|ll|r|r|r|r|}
\hline & & EME & DISTRIBUTE & PROCEDURE & INTERACT \\
\hline EME & Pearson Correlation & 1 & $.678^{* *}$ & $.673^{* *}$ & $.216^{* *}$ \\
& Sig. (2-tailed) & & .000 & .000 & .000 \\
& $\mathrm{~N}$ & 401 & 401 & 401 & 401 \\
\hline DISTRIBUTE & Pearson Correlation & $.678^{* *}$ & 1 & $.224^{* *}$ & .071 \\
& Sig. (2-tailed) & .000 & & .000 & .159 \\
& $\mathrm{~N}$ & 401 & 401 & 401 & 401 \\
\hline PROCEDURE & Pearson Correlation & $.673^{* *}$ & $.224^{* *}$ & 1 & $.172^{* *}$ \\
& Sig. (2-tailed) & .000 & .000 & .001 \\
& $\mathrm{~N}$ & 401 & 401 & 401 & 401 \\
\hline INTERACT & Pearson Correlation & $.216^{* *}$ & .071 & $.172^{* *}$ & 1 \\
& Sig. (2-tailed) & .000 & .159 & .001 & \\
& $\mathrm{~N}$ & 401 & 401 & 401 & 401 \\
\hline
\end{tabular}

**. Correlation is significant at the 0.01 level (2-tailed).

Source: Researcher's fieldwork (2018)

Table 5 shows that employee engagement is positively and significantly related to all the dimensions of organisational justice namely 
distributive justice $\left(\mathrm{r}=.678^{* *}, \mathrm{p}=000<0.05\right)$, procedural justice $\left(\mathrm{r}=.673^{* *}\right.$, $\mathrm{p}=000<0.05)$, and interactional Justice $\left(\mathrm{r}=.216^{* *}, \mathrm{p}=000<0.05\right)$.

\section{Regression Analysis Results}

Table 6: Regression Analysis Results

\begin{tabular}{|c|c|c|c|c|c|c|}
\hline \multirow{2}{*}{\multicolumn{2}{|c|}{ Model }} & \multicolumn{2}{|c|}{ Unstandardized Coefficients } & $\begin{array}{l}\text { Standardized } \\
\text { Coefficients }\end{array}$ & \multirow[b]{2}{*}{ Test statistic } & \multirow{2}{*}{$\begin{array}{c}\mathrm{P} \\
\text { value }\end{array}$} \\
\hline & & $\mathrm{B}$ & Std. Error & Beta & & \\
\hline \multirow[t]{4}{*}{1} & (Constant) & .626 & .084 & & 7.408 & .000 \\
\hline & DISTRIBUTE & .364 & .017 & .552 & 21.530 & .000 \\
\hline & $\begin{array}{l}\text { PROCEDUR } \\
\text { E }\end{array}$ & .353 & .017 & .534 & 20.571 & .000 \\
\hline & INTERACT & .075 & .022 & .085 & 3.352 & .001 \\
\hline \multicolumn{2}{|c|}{ D.W } & R Square & $\begin{array}{l}\text { Adjusted R } \\
\text { Square }\end{array}$ & Overall Std. Error & $\mathrm{F}$ & Sig. \\
\hline \multicolumn{2}{|c|}{1.999} & .752 & .750 & .19810 & 401.794 & $.000^{\mathrm{a}}$ \\
\hline
\end{tabular}

The regression results also show that organisational justice constructs: distributional, procedural and interactional when grouped together has Fstatistic of 401.794 at Prob (F-statistic) value of 0.00000 . This means that, overall there exist statistical significant relationships between organisational justice and employees engagement in tertiary institutions in Edo State at 5\% level of significance.

There is also a highly statistical significant relationship between distributional justice $(\mathrm{t}=21.530 ; \mathrm{p}=0000<0.05)$, procedural justice $(\mathrm{t}=20.571$; $\mathrm{p}=0000<0.05)$, and interactional justice $(\mathrm{t}=3.352 ; \mathrm{p}=001<0.05)$ and employee engagement in tertiary institutions in Edo State. The results showed that such relationship is positive, suggesting that all the dimensions of organisational justice have positive impact on employee engagement.

\section{Discussion of Findings}

The findings that distributive justice significantly and positively influence employee engagement in the tertiary institutions in Edo State corroborate the position of Gupta and Kumar (2012) that distributive justice strongly and significantly affect employee engagement in Indian business context or among employees working in Indian organizations and subsidiaries of multinational corporations (MNCs). Our findings also confirm the work of Strom (2014) that procedural and distributive justice positively related to work engagement under the conditions of low transactional leadership among 348 employees in USA. They support the empirical study of Özlem, Özgür \& Meltem (2017) among healthcare personnel working in a state hospital in Turkey that distributive justice and work engagement are significant and have a positive linked. 
The findings also agreed with the empirical position of Ghosh, Rai and Sinha (2017) among sampled 284 bank employees in India that distributive significantly and positively influence job engagement and organizational engagement. Moreover, Igbinomwanhia and Akinmayowa, (2014) demonstrated that citizenship behaviour, which is a related construct to engagement is significantly determined by employees' perception of distributive justice. These findings are in alignment with the study of Ucho and Atime (2013) that distributive justice has a significant impact on OCB dimensions of altruism, conscientiousness, sportsmanship and civic virtue. Our findings also confirm the revelation that distributives significantly related to similar/related constructs of engagement such OCB among teachers of public secondary schools in the Akwa Ibom State of Nigeria (Efanga \& Akpan, 2015), psychological well-being of employees in the local government service of Osun State, Nigeria (Ajala \& Bolarinwa, 2015) and employee satisfaction among staffs of seven selected banks operating in Rumuokoro-Uniport axis of Port Harcourt, Rivers State, Nigeria (Okocha \& Anyanwu, 2016), and employees commitment in manufacturing firms in Ibadan, Oyo State, Nigeria (Ajala, 2015).

They however deviated from the work of Amazue, Nwatu, Ome and Uzuegbu (2016) that distributive justice failed to predict work alienation, which is opposite pole of dedication and absorption aspect of engagement among Academic And Non-Academic Staff Of University Of Nigeria. Our findings are also contrary Arif and Ibrahim (2015) study that distributive justice though positively influence quality relationship between leader and subordinate, it failed to predict the level of employees' work engagement and there is a full mediation effect of LMX on interactional justice and employee work engagement among 218 employees (accountants, managers, passenger handling officers, reservation agents, sales employees, and supervisors) from an airline company in Middle East.

The second findings that procedural justice significantly and positively influences employee's engagement in the tertiary institutions in Edo State are in agreement with several empirical studies. They are in confirmation with the empirical study of Karatepe (2011) that procedural justice significantly influence work engagement among full-time frontline hotel employees in Abuja, Nigeria. They also collaborate with the position of Gupta and Kumar (2012) procedural justice had a significant strong impact on employee engagement in Indian. Our findings also agreed with the empirical revelation Özlem, Özgür and Meltem (2017) that procedural justice has a significant and positive linked with work engagement in Turkey.

Our findings also agreed with the empirical position of Ghosh, Rai and Sinha (2017) that procedural justice significantly and positively influence job engagement and organizational engagement among bank employees in 
India. They confirm the work of Igbinomwanhia and Akinmayowa, (2014) demonstrated that citizenship behaviour, which is a related construct to engagement is significantly determined by employees' perception of procedural. They also support the wok of Ucho and Atime (2013) and Balogun, Ojedokun and Owoade, (2016) that procedural justice has a significant impact on OCB dimensions (altruism, conscientiousness, sportsmanship and civic virtue).

Our findings are consistent with several empirical revelations that procedural justice significantly related to related constructs of engagement such OCB among teachers of public secondary schools in the Akwa Ibom State of Nigeria (Efanga \& Akpan, 2015), psychological well-being of employees in the local government service of Osun State, Nigeria(Ajala \& Bolarinwa, 2015) and employee satisfaction among staffs of seven selected banks operating in Rumuokoro-Uniport axis of Port Harcourt, Rivers State, Nigeria (Okocha \& Anyanwu, 2016), and employees commitment in manufacturing firms in Ibadan, Oyo State, Nigeria (Ajala, 2015), job performance among lecturers in the Federal Universities in the South-South zone of Nigeria (Efanga, Aniedi \& Gomiluk , 2015). They also however disagreed with the work of Amazue, Nwatu, Ome and Uzuegbu (2016) procedural justice failed to predict work alienation as well as the work of He, Zhu and Zheng (2016) in leading financial service organization in the United Kingdom that the procedural justice has no direct effect on employee engagement but affect engagement through organizational and moral identity centrality.

The third findings that interactional justice significantly and positively influences employee's engagement in the tertiary institutions in Edo State confirm the empirical revelation of Gupta and Kumar (2012) that interaction justice significantly impact on employee engagement in Indian business context. This finding also confirm the work of the empirical study of Özlem, Özgür and Meltem (2017) interactional justice and work engagement have significant and positive linked among healthcare personnel working in a state hospital in Turkey. It also agreed with the empirical position of Ghosh, Rai and Sinha (2017) that interactional justice significantly and positively influences job engagement and organizational engagement among bank employees in India.

The findings of this study also confirm the works of Igbinomwanhia and Akinmayowa, (2014) that employees' perception of interactional justice significantly determines citizenship behaviour. They also support the works of Ucho and Atime (2013) and Balogun, Ojedokun and Owoade, (2016) that interactional justice significantly impacts on OCB dimensions (altruism, conscientiousness, sportsmanship and civic virtue). (Efanga \& Akpan, 2015), psychological well-being of employees in the local government service of 
Osun State, Nigeria (Ajala \& Bolarinwa, 2015) and employee satisfaction among members of staff of seven selected banks operating in RumuokoroUniport axis of Port Harcourt, Rivers State, Nigeria (Okocha \& Anyanwu, 2016), and employees commitment in manufacturing firms in Ibadan, Oyo State, Nigeria (Ajala, 2015), job performance among lecturers in the Federal Universities in the South-South zone of Nigeria (Efanga, Aniedi \& Gomiluk, 2015).

\section{Policy Implications:}

1. Management of tertiary institutions in Edo State should increase and promote fairness in distribution of reward among employees. This can be done by rewarding employees according to their efforts, contribution, needs, responsibilities, relevant skills, educations and training acquired/received.

2. Management of tertiary institutions in Edo State should also promote fairness in the procedure employees under to get work done and promoted. This can be done by pursuing those policies or procedures that will ensure employees are promoted on time and as when due, ensuring work rules is applied consistently across all employees, and the rules provided in getting work done are not be stringent but provide opportunities for employees to voice, appeal or challenge decisions.

3. Management of tertiary institutions in Edo State should also sustain its efforts in fostering justice in the interaction especially the information provided to employees and how members of organization treat, related and discuss issues. This can be done by ensuring that supervisors provide employees with accurate, timely and adequate information to perform job. Information justice can also be improve by ensuring supervisors take time to clearly explain and communicated roles and responsibilities to employees and the employees understood what is communicated to them. More so, management of tertiary institutions in Edo State should ensure employees are provide with useful feedback regarding a decision and its implementation and get fair hearing and result when they requests for additional information about the decision. Justice in interactional can also be increase by directing supervisor suppresses personal biases in work allocation and when treating subordinates, uphold ethical and moral standards in supporting and treating employees, refrains from improper remarks/comments when talking to subordinates, and treating all employees with dignity, politeness, kindness, consideration and in truthful manner. 


\section{References:}

1. Adams, J.S. (1965). Inequity in social exchange. New York: Academic Press.

2. Ajala, E. M. (2015). The influence of organisational justice on employees' commitment in manufacturing firms in Oyo State, Nigeria: implications for industrial social work. African Journal of Social Work, 5(1), 92-101.

3. Ajala, E. M. (2016). Perceived correlation between organisational justice and employees' organisational citizenship behaviours in the civil service of Ondo and Oyo State, Nigeria. Ife Psychologia 2016, 24(1), 1-10

4. Ajala, E. M. \& Bolarinwa, K. O. (2015). Organisational justice and psychological well-being of employees in the local government service of Osun State, Nigeria. An International Multidisciplinary Journal, Ethiopia, 9(4), 55-72

5. Akanbi, P.A., \& Ofoegbu, O.E. (2013). Impact of perceived organisational justice on organisational commitment of a food and beverage firm in Nigeria. International Journal of Humanities and Social Science, 3(14), 207-212.

6. Albrecht, S.L., Bakker,A. B, Gruman, J, A ., , W. H. Saks, \& A, M. (2015). Employee engagement, human resource management practices and competitive advantage: An integrated approach. Journal of Organizational Effectiveness: People and Performance, 2 (1), 7-35.

7. Amazue, L. O., Nwatu, O.H., Ome, B.N. \& Uzuegbu, C.N. (2016). Relationship between perceived leadership style, organizational justice and work alienation among Nigerian university employees. Journal of Business and Management, 18(4), 76-85.

8. Ambrose, M. L., Seabright, M. A., \& Schminke, M. (2002). Sabotage in the workplace: The role of organizational injustice. Organizational Behavior and Human Decision Processes, 89, 947-965.

9. Arif, H. \& Ibrahim, H, (2015). Organisational justice and employee work engagement: LMX as mediator. J. International Business and Entrepreneurship Development, 5(2), 78-86.

10. Baharifar A, Javaheri \& Kamel, M. (2012). The study of organization's ethical values outcomes. Police Hum. Dev., 7(1), 95-118.

11. Bahrami, M. A, Montazeralfaraj, R., Gazar, S. A \& Tafti, A.D. (2014). Relationship between organizational perceived justice and organizational citizenship behavior among an Iranian hospital's employees. Electronic Physician, 6(2), 56-64. 
12. Bakker, A.B. \& Demerit, E. (2014). Job demands-resources theory. Wiley Blackwell: New York, NY.

13. Balogun, S. K, Ojedokun, O, \& Owoade, O. A. (2016). Influence of perceived organizational justice on performance of organizational citizenship behavior among employees of a Nigerian organization. International Review of Business and Social Sciences, 1(2), 1-16.

14. Bies, R. J., \& Moag, J. F. (1986). Interactional justice: Communication criteria of fairness. In R. J. Lewicki, B. H. Sheppard, \& M. H. Bazerman (Eds.), Research on negotiations in organizations, 1, 43-55. Greenwich, CT: JAI Press

15. Bing, M.N., Davison, H.K., Garner, B.L., Ammeter, A.P., \& Novicevic, M.M. (2009).Employees' relations with their organization: The multidimensionality of the equity sensitivity construct. International Journal of Management, 26, 436-444.

16. Bowen, D. E., \& Gilliland, S. W. (2007). The management of organisational justice. Academy of Management Perspectives, 21(4), 34-48.

17. Bryman, A., \& Cramer, D. (1997). Quantitative data analysis with SPSS for windows: A guide for Social Scientists. London: Routledge.

18. Cassar, V., \& Buttigieg, C. S. (2015). Psychological contract breach, organizational justice and emotional well-being. Personnel Review, 44 (2), 217-235

19. Ceylan, A., \& Sulu, S. (2011). Organizational injustice and work alienation Ekonomie a Management, 2, 65-87.

20. Colquitt, J. A. (2001). On the dimensionality of organizational justice: A construct validation of a measure. Journal of Applied Psychology, 86, 386-400.

21. Cremer, D.D. (2005). Procedural and distributive justice effects moderated by organisational identification. Journal of Managerial Psychology, 20(1), $4-13$.

22. Dabbagh, P., Esfahani, A, \& Shahin, A. (2012). Studying relationship between perceived organizational justice and organizational salience (Case Study: Khorshid Hospital's Personals). Interdisciplinary J. of Contemporary Res. Bus, 3(10), 468-478.

23. Eder, P. \& Eisenberger, R. (2015). Perceived organizational support: reducing the negative influence of coworker withdrawal behavior. Journal of Management, 1, 55-6

24. Efanga, S. I \& Akpan, G.M. (2015). The relationships between organizational justice and teachers' organizational citizenship 
behaviour in secondary schools in Akwa Ibom State, Nigeria. Asian Journal of Management Sciences \& Education, 4(3), 70-82.

25. Ghosh, P., Rai, A., \& Sinha, A. (2017). Organizational justice and employee engagement: Exploring the linkage in public sector banks in India. Personnel Review, 43(4), 628-652.

26. Greenberg J. (1987) Determinants of perceived fairness of performance evaluation. Journal of Applied Psychology, 71, 340342.

27. Greenberg, J. (2005). Using explanations to manage impressions of performance appraisal fairness. Journal of Employee Responsibilities and Rights, 4(1), $51-60$.

28. Greenberg, J., \& Colquitt, J. A. (2015). Handbook of organisational justice. Mahwah, NJ: Lawrence Erlbaum Associates.

29. Gupta, V., \& Kumar, S. (2012). Impact of performance appraisal justice on employee engagement: a study of Indian professionals. Employee Relations, 35(1), 61-78.

30. He, H. Zhu, W., \& Zheng, X (2016). Procedural justice and employee engagement: roles of organizational identification and moral identity centrality. J Bus Ethics, 3, 67-74.

31. Igbinomwanhia, O. R., \& Akinmayowa, J. T. (2014). Determinants of citizenship behavior in Nigerian organizations. European Journal of Business and Management, 6(35), 155.

32. Kahn, W. A. (1990). Psychological conditions of personal engagement and disengagement at work. Academy of Management Journal, 33, 692-724.

33. Karatepe, O. M (2011). Procedural justice, work engagement, and job outcomes: evidence from Nigeria, Journal of Hospitality Marketing \& Management, 20 (8), 855-878.

34. Ledimo, O \& Hlongwane, V.C. (2017). The role of organisational justice on employee engagement within a public service organization. La Pensee Multidisciplinary Journal, 76, (11), 1-13

35. Macey, W. H., \& Schneider, B. (2008). The meaning of employee engagement. Industrial and organizational Psychology, 1(1), 3-30.

36. Macey, W. H., Schneider, B., Barbera, K. M., \& Young, S. A. (2009).Employee engagement: Tools for analysis, practice, and competitive advantage. John Wiley \& Sons.

37. May, D. R., Gilson, R. L., \& Harter, L. M. (2004). The psychological conditions of meaningfulness, safety and availability and the engagement of the human spirit at work. Journal of occupational and organizational psychology, 77(1), 11 37. 
38. Moorman, R. H. - Niehoff, \& B. P. Organ, D. W. (1993). Treating employees fairly and organizational citizenship behavior: Sorting the effects of job satisfaction, organizational commitment and procedural justice. Employee Responsibilities and Rights Journal, 6 (3), 209-225.

39. Monanu, O. Okoli, I. Ezeliora M. \& Okeke, P. (2016). Organisational Justice and Organisational Citizenship Behaviours among Academic Staff of Private Universities in Southeast Nigeria. Journal of Economics and Sustainable Development, 5(21), 12-20.

40. Nabatchi, T., Bingham, L. B., \& Good, D. H. (2007). Organizational justice and workplace mediation: a six factor Model. International Journal of Conflict Management, 18 (2), 148176.

41. Nunnally, J. C. (1978). Psychometric theory (2nd ed.). New York: McGraw-Hill.

42. Nwinyokpugi, P. (2014). Employee engagement and workplace harmony in Nigeria civil service. International journal of innovative research, 4(2), 62-75.

43. Oge, G., M., Ifeanyi E., O., \& Charles-Gozie, A. (2015). Organizational justice and counterproductive work behaviour. Journal of Business \& Management Studies, 1(2), 1-10

44. Ohiorenoya J.O. (2013) Organization culture, knowledge management practices and

45. organizational performance in Nigerian Universities. $\mathrm{PhD}$ Dissertation submitted to the

46. School of Postgraduate Studies, University of Benin, Benin City

47. Ohiorenoya J.O \& Eboreime O.F (2014) Organization culture types and performance in

48. Nigerian Universities. European Journal of Business and Management. 6 (18), 80-88

49. Okocha, B. F., \& Anyanwu, S.A.C. (2016). Organizational justice and employee satisfaction: A study of selected Banks in Port Harcourt. International Journal of Advanced Academic Research Social \& Management Sciences, 2(9), 62-74.

50. Omoruyi, Q., Chipunza, C., \& Samuel, M.O. (2011). Perceptions of justice and extra-role behaviours of survivors after organisational restructuring at a consolidated bank in Nigeria. SA Journal of Human Resource Management, 9(1), 344-356

51. Rothbard, N. P. (2001). Enriching or depleting? The dynamics of engagement in work and family roles. Administrative Science Quarterly, 46(4), 655-684. 
52. Saks, A. M. (2006). Antecedents and consequences of employee engagement. Journal of Managerial Psychology, 21, 600-619.

53. Schaufeli, W. B., Salanova, M., González-Romá, V., \& Bakker, A. B. (2002). The measurement of engagement and burnout: A two sample confirmatory factor analytic approach. Journal of Happiness Studies, 3, 71-92.

54. Shantz, A., Alfes, K., Truss, C., \& Soane, E. (2013). The role of employee engagement in the relationship between job design and task performance, citizenship and deviant behaviours. The International Journal of Human Resource Management, 24(13), 2608-2627.

55. Shaw, H. (2005). Employee engagement and well-being a moderation model and implications for practice. Journal of Leadership \& Organizational Studies, 21(1), 43-58.

56. Ucho, A. \& Atime, E. T. (2013). Distributive justice, age and organizational citizenship behaviour among non-teaching Staff of Benue State University. International Journal of Psychology and Behavioral Sciences, 3(4): 77-8

57. Uzondu, C.N., Adibe, K., Aloh, E. E. \& Okafor, M. E. O. (2014). Influence of supervisor's incivility, perceived organizational justice and gender on organizational commitment. International Journal of Information Research and Review, 1(11), 165-172.

58. Walumbwa F.O., Cropanzano R., \& Hartnell C.A. (2009). Organizational justice, voluntary learning behavior, and job performance: A test of the mediating effects of identification and leader-member exchange. Journal of Organizational Behavior, 30(8), 1103-1126. 